\title{
The Urgency for the Implementation of Simultaneous Regional Elections During the Covid- 19 Pandemic in Indonesia in 2020
}

\author{
Rasyidin $^{1}$, Fidhia Aruni ${ }^{2}$
}

\author{
${ }^{1}$ Universitas Malikussaleh \\ ${ }^{2}$ Sekolah Tinggi Ilmu Administrasi Nasional \\ *Corresponding author: Email: rasyidin@unimal.ac.id
}

\begin{abstract}
This article discusses the urgency for simultaneous Regional Elections during the Covid-19 pandemic in Indonesia in 2020. The Regional Elections (Pilkada) in Indonesia will be conducted simultaneously by 270 regions, consisting of nine provincial-level regional heads, 224 district level regional heads, and 37 regional head of City level. Perppu No. 2 of 2020 concerning Regional Elections states that it will be held on December 9, 2020. The Covid-19 pandemic has hit all parts of the world and causes deaths, including in Indonesia. Regional Elections will still be held based on various considerations by stakeholders. This article examines the urgency of implementing simultaneous Regional Elections and its obstacles during the Covid-19 pandemic. It is a qualitative study and uses a literature review as the data. The results show that Covid-19 Pandemic affects political activities, which involves large numbers of people. Meanwhile, people are required not to gather/do activities in great numbers because there is a risk of spreading the virus, which ignores the government's spirit to break the chain of spreading the virus itself. However, the Regional Elections (Pilkada) ar considered to have crucial urgency and very urgent. Besides, it raises questions about whether it is due to bureaucratic factors that cannot be empty in the government structure or other political factors that require the elections to be held.
\end{abstract}

Keywords: Pilkada, Pandemic Covid-19, Indonesia

\section{INTRODUCTION}

Simultaneous Regional Elections are one of the political activities held for regions, both provinces, districts, and cities where regional heads such as Governors, Regents, and Mayors have expired political terms and need to organize the Regional Elections again. In 2020, 270 regions are covering nine provinces, 224 regencies, and 37 cities in Indonesia that need to conduct Pilkada (Regional Elections) so that the implementation is arranged to become the simultaneous Regional Elections in Indonesia.

Planning for the implementation of simultaneous Regional Elections that have been completed and stipulated in Law Number 1 of 2015 concerning the Election of Governors, Regents and Mayors which previously was still in the form of Government Regulation in Lieu of Law (Perppu) Number 1 of 2014, states that the simultaneous Regional Elections will be held on September 23, 2020 .

Since December 2019, a new virus known as Covid-19 has spread in Wuhan City, China, and has spread throughout the world, including Indonesia. The Indonesian government officially announced that there were people infected with the covid-19 virus in March 2020, and the spread and increase in the 
number of infected Indonesians have continued to increase since then. There are several policies taken by the Indonesian government, such as implementing Physical Distancing, Work From Home, and PSBB (Large-Scale Social Restrictions) as a form of preventing the expansion of the spread of the Covid19 virus in Indonesia (Akbar \& Darnis, 2020).

The Indonesian government has determined the Covid-19 virus as a pandemic and a non-natural disaster where the public should not carry out various activities in a crowded mass because of intense interactions either with positive communities or through people with the category of People Without Symptoms (OTP) can transmit the virus. Since the pandemic, All sectors in Indonesia have experienced changes from various aspects, such as community life structures, government, economy, politics, social, culture, and religion.

So far, Regional Elections (Pilkada) activities have always involved large numbers of people. Campaign activities generally always involve a crowd of supporters of regional head candidate pairs. Meanwhile, to break the chain of the Covid-19 pandemic, the government must implement social restrictions, one of which is not allowing activities with large crowds.

The Indonesian government through Perppu Number 02 of 2020 concerning the Third Amendment to Law Number 1 of 2014 concerning Elections for Governors, Regents, and Mayors become a Law. It states that if part of the electoral area or the entire electoral area occurs unrest, security disturbances, natural disasters, non-natural disasters, or other disturbances, it will result in some stages of simultaneous elections being unable to be implemented. Instead, it was carried out after the postponement determined by the General Election Commission (KPU) decision signed by President Jokowi on May 4, 2020.

Perppu has been a polemic in 2020 when the increase in the number of Covid-19 patients in Indonesia has spread to all regions, including areas that will carry out Pilkada. In this case, there are tugof-war, pros, and cons to the simultaneous Regional Elections because the Government of Indonesia through the KPU will continue to carry out the elections in 2020. The implementation was scheduled for September 23, 2020, and was later postponed to December 9, 2020. Many parties consider that the government seems to be forcing simultaneous Regional Elections to be carried out in the Covid-19 pandemic because it is concerned with political interests rather than the interests of public health and safety.

The simultaneous Pilkada implementation during the Covid-19 pandemic raises the question of what is the real urgency of the government, which still wants to hold simultaneous Regional Elections while the death rate and the spread of the Covid-19 virus are still increasing until now. The simultaneous Regional
Head Election is not under the government's mission in breaking the chain of transmission of the Covid-19 virus in Indonesia because the implementation of Regional Elections in each region will make candidate pairs carry out campaigns to seek community support. So far, campaign activities are always laden with crowds and very dangerous during the current covid19 pandemic in Indonesia.

This study aims to examine the urgency of implementing simultaneous Regional Elections during the Covid-19 Pandemic in Indonesia in 2020. What is the urgency for the Indonesian government to continue to impose simultaneous Regional Elections during the Covid-19 pandemic?. This study uses the literature review method by analyzing various kinds of issues and sources from various media and other research articles related to the implementation of simultaneous Regional Elections in Indonesia during the Covid-19 pandemic.

To strengthen the discussion above, the researchers divide the article into several sections. The first part is an introduction containing the background of the simultaneous Regional Elections during the Covid-19 pandemic and a description of Indonesia during the Covid-19. Then the second part concerns the urgency of implementing simultaneous Regional Elections during the Covid-19 Pandemic in Indonesia in 2020. It explains the results of the analysis that cause the Government to continue to hold Regional Elections simultaneously. The third part is the contribution of researchers to this research, and the last is a closing which contains the essence of the whole discussion in the article.

\section{LITERATURE REVIEW}

\subsection{Politics}

Politics is a strategy for managing the State and is a science that plays a role in the administration of the State. All activities relating to the State and State institutions are political. Karl W. Deutsch in Rasyidin and Fidhia (2016, p 17) states that politics is a decision making through public means.

\subsection{General Elections}

Matori Abdul Djalil in Putu Eva (2018, p 92) claims that General Election is to provide certainty over the constitutional transfer of leadership and power to produce legitimate leaders. Meanwhile, Syamsudin Haris states that the general election is both an institution and a political practice that allows the formation of a representative government.

Based on the definition of elections presented above, it concludes that election administration is closely related to the process of transferring leadership, implementing democracy, and the realization of people's sovereignty. The importance of the implementation of elections in the country has been conveyed by Marulak Pardede in Putu Eva (2018, p 93) as follows: 
1. to exercise people's sovereignty;

2. to elect people's representatives;

3. to ensure or at least update the agreement of the citizen party;

4. to influence the behavior of citizens; and

5. to educate the rulers to rely more on the agreement of the people rather than coercion for maintaining their legitimacy.

\subsection{Democracy}

Democracy is government by the people, where this definition is interpreted literally as a fundamental understanding and has been widely used so far. Democracy is also defined as government by the people, and the government acts under the will of the people. The ideal democratic government must work well following the aspirations and needs of its people, Y. Widianigsih (2017. p 3).

\section{RESEARCH METHOD}

This study applies a qualitative approach that produces descriptive analysis data in the form of written or spoken words from people and observed behavior, Moleong J Lexy (2012, p. 4). This qualitative study uses descriptive-qualitative analysis methods, as well as qualitative exploratory. This study uses a literature review method by analyzing various kinds of issues and sources from various media and other articles related to the implementation of simultaneous regional elections in Indonesia during the Covid-19 pandemic.

\section{RESULT AND DISCUSSION}

4.1. The Urgency of Simultaneous Regional Elections during the Covid-19 Pandemic in Indonesia in $\mathbf{2 0 2 0}$.

The simultaneous Regional Elections in Indonesia during the Covid-19 pandemic in 2020 seems to be forced because the Government is also trying to fight the spread of the Covid-19 virus since early 2020. Until now, there has also been no clinically tested drug or vaccine that can cure the virus.

Since the implementation of the New Normal as a new order of life for the Indonesian people through the implementation of strict health protocols and freeing people to be able to do activities as before, the number of positive cases of Covid-19 has increased. Currently, there are 404,048 people with a total of 13,701 deaths and 60,569 people who are currently undergoing treatment (data source: Indonesian Covid-19 Task Force, October 30, 2020).

The Covid-19 pandemic has an impact on the entire system of life in Indonesia. One of them is the political aspect, especially the democratic party that is also an urgent agenda in 2020, namely the simultaneous Regional Elections, which were scheduled for 23 September 2020, and then postponed to 9 December 2020 due to various considerations.
According to the Head of Legislation Section of the Directorate General of Regional Autonomy of the Ministry of Home Affairs (Kemendagri) Saydiman Marto, there are five urgencies for the simultaneous Regional Elections in 2020 during the Covid-19 pandemic, including the implementation of Regional Elections in 2020 as a joint decision between the government, DPR and election organizers, namely KPU. Second, a form of maturity of the Indonesian nation in democracy and making the Regional Elections a momentum to fight covid-19. Third, reduce the practice of local government leadership, which is led by too many temporary officials or task forces (Plt) who have limited authority. Fourth, to handle Covid-19 through a regional head who is trusted by the community. Fifth, the Regional Elections aim to spur the economy in a crisis caused by the Covid-19 pandemic (source: Kompass).

Meanwhile, the KPU has its reasons for holding Regional Elections simultaneously during the Covid-19 Pandemic. I Dewa Kade Wiarsa Raka Sandi, as a member of the KPU, said that simultaneous Regional Elections must continue to be held in 2020 because the KPU implements the applicable regulations, no one party guarantees the covid-19 pandemic will end, there is a constitutional right to choose and be elected in the administration of democracy the five-year change of leadership for regional heads, and the budget for simultaneous Regional Elections has been disbursed in 2020 amounted to IDR 4.1 trillion. If the Regional Elections are postponed until the following year, the disbursed budget will be wasted because it has passed the budgeting year (Source: Republika).

Tito Karnavian is a Minister of Home Affairs (Mendagri) and expressed his belief about the continuation of the simultaneous Regional Elections during the Covid-19 pandemic after meeting with the South Korean Ambassador on June 8, 2020. He said that the success of South Korea in implementing the Legislative Election in April 2020 should be emulated and is admired because the implementation of strict health protocols from the start to the polling day is indeed a very good reference and will be a reflection of the implementation of the simultaneous elections in Indonesia in December (source: Media Indonesia).

The statements above show that the Government urgency in implementing simultaneous Regional Elections during the Covid-19 pandemic in 2020 is related to bureaucratic reasons and pragmatism (budget) reasons. The government does not at all use public health and safety as an excuse to postpone the simultaneous Regional Elections in Indonesia and chooses to continue to carry out these simultaneous elections.

The Indonesian government seems to have forgotten the Latin term that says Solus Populi Suprema Lex Esto, namely the safety of the people is the highest law. Precisely, the safety and health of the 
people during the Covid-19 pandemic in 270 areas of simultaneous Regional Elections for both regencies and cities in Indonesia. Even though the government argues that the simultaneous Regional Elections will strictly implement the health protocol during the Covid-19 period, many pairs of candidates and supporters have violated health protocols, such as conducting convoys to register candidate pairs at the local KPU, mass gathering in large numbers in several declarations, and campaigning without using masks as personal protection, and other violations of health protocol.

The Election Supervisory Agency (Bawaslu) has noted that there are 375 health protocol violations in the first ten days of the campaign from October 6 to October 15, 2020. Bawaslu claims that the high number of health protocol violations is caused by campaigns using face-to-face methods that cause a crowd of supporters of candidate pairs. According to the health protocol during the Covid-19 pandemic, face to face campaign is a violation because it triggered the spread of the Covid-19 virus among the community (source: Kompas).

During the Covid-19 emergency like today, all political maneuvers and mechanisms become riskier because campaign activities are still carried out face to face and in large numbers. Of course, the candidate pairs will carry out their political strategy by mobilizing the masses to win the democratic party. Moreover, the urgency of the government to carry out simultaneous Regional Elections during the Covid-19 pandemic shows carelessness to the health and safety of the people as a priority.

Herman Heller (in Soepandji, 2017: 24) said that the essence of the state is an authoritative unit to decide urgent things for the country and an authoritative entity that collaborates in achieving the stated goals of the country. It means that the task of the state is to decide crucial things to ensure the safety of the nation, which is stated in the fourth paragraph of the preamble to the 1945 Constitution: to protect the entire Indonesian and all Indonesian bloodshed. In this case, it aims to protect the nation from the potential dangers of the Covid-19 virus, which is still unknown when it will disappear (Akbar \& Darnis, 2020).

The simultaneous Regional Elections are an effort to create local accountability, political equity, and local responsiveness. It must be able to bring comprehensive results and bring people to feel the improvement of social, political, and economic conditions (Rizki \& Hilman, 2020). The simultaneous Regional Elections during the Covid-19 pandemic should provide certainty regarding public health and safety, not only providing certainty about the continuation of democracy, bureaucracy, and pragmatism considerations as the urgency of implementing simultaneous Regional Elections during the Covid-19 pandemic.
Simultaneous Regional Elections are full of mass crowds in their political activities, which should also require awareness from the public in political participation, especially in campaign activities that must apply strict health protocols. Because of the regulations by the government, the community must have high awareness in implementing these policies as political participants in the democratic party at the end of the year.

\section{CONTRIBUTION}

This study is expected to be able to add scientific knowledge in the development of academic literature as an insight enhancer for the community and especially for the Government in carrying out general elections and Regional Elections by paying attention to aspects of public health and safety compared to political, bureaucratic, and pragmatism aspects in the COVID-19 pandemic with an increase in positive patients for Covid-19 in Indonesia and considering the mission of the Indonesian Government to break the chain of spreading the Covid-19 virus.

\section{CONCLUSIONS}

Based on the discussion above, there are several conclusions related to the urgency of implementing simultaneous Regional Elections during the Covid-19 pandemic in Indonesia in 2020, including:

First, the 2020 simultaneous Regional Elections should be held on September 23, 2020, but is postponed due to a non-natural disaster, namely the Cobid-19 pandemic. However, based on the approval by the government, DPR, and KPU, the Covid-19 task force team, the simultaneous Regional Elections will continue to be held on December 9, 2020, based on various considerations.

Second, there are many pros and cons of carrying out the simultaneous Regional Elections because they are considered to have no urgency, especially during the Covid-19 pandemic. Political activities that generally occur at democratic parties in Indonesia are campaign activities involving many masses, while during the Covid-19 pandemic, mass crowds are strictly prohibited because they can trigger the spread and increase of positive Covid-19 numbers and are not under the spirit of the Indonesia government to cut its eyes the chain of covid-19 in Indonesia.

Third, based on the results of the analysis, it shows that the urgency of the government to carry out simultaneous Regional Elections in the middle of the Covid-19 pandemic is due to 3 reasons, including:

1. Bureaucracy; the government argues that the position of regional head should not be vacant, and there should not be too many 
officials performing tasks. If the Regional Elections is postponed, it will lead to the vacant positions of regional heads in various regions, whose regional heads have expired their term of office.

2. Democracy, the government argues that there are considerations of constitutional rights to choose and be elected in the implementation of democracy in the five years of the succession of regional heads. If it is postponed, it will damage the democratic order in Indonesia.

3. Pragmatism; the government argues that there is an economic factor, namely the disbursed 4.1 Trillion Rupiah for simultaneous Regional Elections. If the simultaneous Regional Elections are postponed, it will be chaos in budget management and will waste the disbursed budget.

\section{ACKNOWLEDGMENTS}

The author is the lecturer at the Faculty of Social and Political Science at Universitas Malikussaleh, and the co-author is the lecturer of State Administration Science at Sekolah Tinggi Ilmu Administrasi Nasional.

\section{REFERENCES}

[1]. Akbar, M.W., \& Darnis, D. (2020). Urgensi Perpu Pilkada Sebagai Kepastian Hukum di Tengah Kondisi Wabah Covid-19. (April), 013.

[2]. Hasibuan, R.P.M. (2020). Urgensitas Perppu Pilkada Di Kala Wabah Pandemi Covid-19. Jurnal Adalah, 4(1). 121-128.

[3]. Hilman, Y.A \& Khoirurrosyidin, Lestarini N (2020). Peta Politik Pemilukada Kabupaten Ponorogo 2020 Di Tengah Pandemi Cobid-19. Jurnal Ilmu Politik, 2(2). 129-148.

[4]. https://amp.kompas.com/kemendagri-sebutada-lima-urgensi-pelaksanaan-pilkada-ditengah-pandemi (diakses pada 23 Oktober 2020)

[5]. https://amp.kompas.com/kemendagri-sebutada-lima-urgensi-pelaksanaan-pilkada-ditengah-pandemi (diakses pada 23 Oktober 2020)

[6]. https://amp.kompas.com/nasional/read/2020/10 /18/07224251/pelanggaran-protokolkesehatan-saat-kampanye-pilkada (diakses pada 30 Oktober 2020)

[7]. https://republika.co.id/berita/qca7uu409/kpujelaskan-urgensi-pilkada-serentak-padadesember (diakses pada 23 Oktober 2020)

[8]. Perppu Nomor 02 Tahun 2020 Tentang Perubahan Ketiga Atas Undang-Undang Nomor 1 Tahun 2014 Tentang Pemilihan Gubernur, Bupati, dan Walikota.
[9]. Realistis Hadapi Pilkada Serentak dalam Editorial Media Indonesia 10 Juni 2020

[10]. Rizki, S.C., \& Hilman, Y.A. (2020). Menakar Perbedaan Opini Dalam Agenda Pelaksanaan Kontestasi Pilkada Serentah Di Tengah Covid19. Jurnal Ilmiah Muqadimah, 4(2), 143-155.

[11]. Undang-Undang Nomor 1 Tahun 2015 Tentang Pemilihan Gubernur, Bupati dan Walikota

[12]. Utomo, W.W. (2020.). Kebijakan Penyelenggaraan Pilkada (Menghadapi Pilkada 2020 Ditengah Covid 19 Dan New Normal). Jurnal Al-Harakah, 3(1), 31-44.

[13]. Wasisto, A \& Prayudi. (2020). Antisipasi Implikasi Demokratis Pilkada Serentak Tahun 2020. Jurnal Info Singkat, 12(12). 25-30.

[14]. Rasyidin dan Fidhia Aruni. (2016). Gender dan Politik Keterwakilan Wanita dalam Politik. Lhokseumawe : Unimal Press

[15]. Antari, P.E.D. (2018). Interpretasi Demokrasi Dalam Sistem Mekanis Terbuka Pemililan Umum Di Indonesia. Jurnal Panorama Hukum, 3(1). 87-104

[16]. Widianingsih Y. (2017) Demokrasi Dan Pemilu Di Indonesia: Suatu Tinjauan Dari Aspek Sejarah Dan Sosiologi Politik. Jurnal Signal, 5(2):1-19. 